\title{
THE APPEARANCE OF CYBERSPACE IN THE RUSSIAN MILITARY OPERATION IN THE LIGHT OF THE RUSSIAN-GEORGIAN WAR IN 2008
}

Original article

Autor(s) CC BY 4.0 Licence

Peer review:

Double blind

Keywords:

Russian-Georgian war in 2008, informational warfare, cyberspace, information operations, cyberspace operations

\author{
Csanád Fekete, Zoltán Sipos \\ Óbuda University, Budapest, Bécsi út 96b, \\ 1034 Hungary
}

\begin{abstract}
The goal of the monograph is to introduce the characteristics and development of Russian concepts in regard to the informational warfare through the incidences of the Russian-Georgian war in 2008. According to most authors, this war can be considered the first armed conflict in history where, in order to achieve certain goals, invasive activities were carried out in cyberspace parallel to the military operations (Hollis, 2011). In order to gain a deeper insight into the subject, a brief review of how information operations formed part of Russian military strategy and ideas in the years prior to the war proved beneficial. A practical place to start the investigation was the Russian experts' conception of the '90s in the field of information operations that became significantly affected by the political and military changes of the era. In the second part of the script we probe how far the information and cyberspace operations that ran parallel to the military operations contributed to achieving the political and strategic goals set during the war. Finally, we present briefly how the conflict contributed to an appreciation of information operations and to the modernisation program of the Russian armed forces.
\end{abstract}




\section{The appearance of cyberspace in Russian military concepts}

For the purposes of this topic, we found it crucial to briefly review the development of Russian concepts in regard to information operations in the years prior to the RussianGeorgian war in 2008. A practical place to start was an investigation into the Russian experts' conception of the '90 in the field of information operations that became significantly affected by the political and military changes of the era. Due to the transitions in the years after the cold war, which took place beyond geopolitical processes by the rapid speed-up of globalisation and urbanisation as well as the fast development of information and communication technologies, new safety challenges emerged. The dissolution of the Eastern bloc led to a further increase in regions of instability, so in the nineties the Balkan-Peninsula and the post-Soviet area witnessed several low intensity conflicts, which resulted in new trouble spots. The realignment of the global power relations measurably narrowed the political and military opportunities of the Russian Federation that emerged as the "successor" of the Soviet Union. In this era, many Russian military experts indicated that the nature of armed conflicts was evolving to a point where achieving information superiority would play an essential role. ${ }^{1}$ It is generally ascertainable that after the bipolar world order's dissolution, due to global changes and technological development, the nature of armed conflict changed too. Therefore, alongside the continental, maritime, air and cosmic battlegrounds a new area of warfare arose, which the experts would refer to as information seat of war. ${ }^{2}$

While introducing the Russian concepts of information operations, we initially found it relevant to mention basic definitions like reflexive control or maszkirovka. According to Diane Chotikul's monograph of 1986, reflexive control is the transmission of specially prepared information to the opponent to incline him to voluntarily make the predetermined decision desired by the initiator of the action (Chotikuk, 1986). In many places, one can read about the practical utilisation of Russian reflexive control and perhaps the simplest example comes from a monograph by an American expert, Thomas L. Timothy (Timothy, 2004) ${ }^{3}$ who writes that at the time of the arms race, during the victory parade organised once a year by the Soviet Army, much larger torpedo heads were fitted to their missiles with the aim of influencing Western analysts. It is also obvious from this example that the Soviet - then later

\footnotetext{
${ }^{1}$ Chekinov, S.G., Bogdanov, S. A: The Nature and Content of a New-Generation War. Military Thought: A Russian Journal of Military Theory and Strategy, 2015, p. 13. http://www.eastviewpress.com/Files /MT_FROM\%20THE\%20CURRENT\%20ISSUE_No.4_2013.pdf, Time of download: 26.05.2016.

${ }^{2}$ Zsolt Haig, István Várhegyi: The cyberspace and interpretation of the cyber warfare. ART OF WAR XVIII, class, p. 2. http://mhtt.eu/hadtudomany/2008/2008_elektronikus/2008_e_2.pdf, Time of download: 2016. 05.22.
} 
the Russian - armed forces had been utilising the theory of reflexive control for a long time, mainly operationally to spread deceit and disinformation. ${ }^{4}$ The deceit or, in other words, "maskirova" was a method already utilised in the second world war and in its essence, camouflage and deceit are used together in order to achieve set goals (Keating, 1981) ${ }^{5}$. During the deceit the Russians employ disinformation techniques that manipulate international public opinion, thus influencing the political decision making of the other party. The manipulation could be totally obvious - due to clear misleading - but it can also occur through delay or spreading rumours. Deceit may be easily spread via misinforming specific people or groups that later sabotage the group from the inside. So the basic goal of the disinformation campaign is to influence people's senses. During the Ukrainian crisis in 2014, the Russians sparked a disinformation campaign throughout Europe that is still ongoing. As a response to this, the CEPA from the United States (Center for European Policy Analysis) set up a continuously updated portal where they regularly publish reports about the propaganda activities of Russia. ${ }^{6}$ Theories on information operations were applied in later conflicts. Even the RussianChechen conflict in the nineties spotlighted the role that information played in military operations, whereby both parties fought "the war" in cyberspace parallel to the military operations on land. The Chechen separatists were among the first to use the web as a tool to achieve their goals. The publication of their political messages and other information on the Internet - including a bank account number in Sacramento that was created to cover their war expenses - helped to unify the Chechen diaspora (Geers, 2008) ${ }^{7}$. The Chechens' further activity against the Russians proved effective too: for example, the publication of pictures taken of the victims that drew the public's attention towards the transgressions of the Russian army. The development of technology made it possible to share videos of attacks made on the Russian military convoys. All these motivated the Russian government to reevaluate the role of cyberspace, further indicated by a statement by Vladimir Putin, the president of the Russian Federation, made in 1999: "Recently, we had given up on this territory... however, now we are taking it up again." 8 The president's words were followed by action, so during the second Chechen war, Russian hackers cracked Chechen websites, the timing and sophistication of

\footnotetext{
${ }^{3}$ https://www.rit.edu/ w-cmmc/literature/Thomas_2004.pdf, Time of download: 22.05.2016.

${ }^{4}$ Ibid.

${ }^{5}$ http://www.dtic.mil/dtic/tr/fulltext/u2/a112903.pdf, Time of download: 24.05.2016

${ }^{6}$ Seen: http://www.infowar.cepa.org/index/

${ }^{7}$ p. 25 , http://www.carlisle.army.mil/DIME/documents/Cyberspace\%20and $\% 20$ the $\% 20$ Changing $\% 20$ Nature $\% 2$ 0of\%20Warfare.pdf, Time of download: 2016.05. 20.

${ }^{8}$ Ibid.
} 
these actions indicating that they had a governmental background. It is important to mention the series of attacks against Estonia in the spring of 2007 that shed new light on the issue of cyber protection. The removal of a Soviet Second World War memorial motivated the attack. As a result of mass attacks against servers used by the Parliament, civil service, ministries, banks, phone companies and media firms, the Internet service jammed, in some cases blacking out for a shorter or longer period. The attack deeply affected the Estonians since the use of the Internet in this state counts as one of the highest in the world. ${ }^{9}$

The choice of targets, the coordination, implementation and effectiveness of the attacks showed that they must have been organised by the authorities. The involvement of the Russian government is obvious, although there is no unequivocal proof (Ruus, 2008) ${ }^{10}$. In spite of the Russians' failure to bring Estonia to heel, the attack found the Estonians as well as NATO unprepared. This case significantly impacted the cyber protection politics of NATO. These examples show that information always played an important role for Russia, whether at war or during peacetime. The appreciation of information during war is also discernable in Russian military documents. The Russian information security doctrine that was published in 2000 describes targets, theories and necessary basic guidelines. The doctrine provides the basis for Russia's information security standpoint. It includes the protection of country and citizens, while also paying attention to the government's interests. It is the citizens' constitutional right to have access to correct information. Russia recognised the importance of information during war and found that in the initial period of a conflict the opponent's operational and managerial capability can be easily weakened via attack. ${ }^{11}$ In regards to military conflicts the document differentiates three types of threats that relate to Russia the first is a source of danger that can spread to the borders immediately. The second is a direct confrontation with the United States, and the Western allies respectively. The third involves the fast and diversified escalation of conflict with China. In connection with the latter two, the document notes that their occurrence is extremely unlikely in the future. ${ }^{12}$ Reportedly, a new

\footnotetext{
${ }^{9}$ Out of 1.34 million Estonians, 75\% are internet users, and Estonia is counted as an e-government leader.

${ }^{10} \mathrm{http}: / /$ www.europeaninstitute.org/index.php/component/content/article?id=67:cyber-war-i-estonia-attackedfrom-russia, Time of download: 28.05.2016.

${ }^{11}$ Information Security Doctrine of the Russian Federation, http://archive.mid.ru//bdomp/nsosndoc.nsf/1e5f0de28fe77fdcc32575d900298676/2deaa9ee15ddd24bc32575d9002c442b!OpenDocument, Downloaded: 01.06.2016.

12 Ibid.
} 
Russian information security doctrine is under construction and its final version will be executed according to expectations by the end of $2016 .^{13}$

Generally, it can be pointed out that as an element of information war, Russia has recently made a point of stressing the development of their cyber capability. The news is always full of stories of how Russian hackers break into industrial computers in different parts of the world and either cause damage or appropriate information. Cyber attacks tend to be associated with Russia because the hackers communicate in Russian among themselves, and the encryption of the malware code also contains Russian words. All this means a growing challenge for NATO and the European Union, who respond to the Russian developments in the information area by strengthening cooperation among the member states.

\section{The processes that led to the Russian-Georgian war and their geopolitical background}

\section{The geopolitical background of the conflict}

In the post-Soviet area that came into existence after the contemporary Soviet Union split up, Russia strove to maintain its political, economic and military influence right from the very beginning. In order to do so, the Commonwealth of Independent States was formed on 8 December 1991 (CIS) with the aim of consolidating the political and economic integration of the member states. ${ }^{14}$ Beside this, some the CIS member states concluded the Collective Security Contract on 15 May 1992 in Tashkent, granting the security, sovereignty and territorial integrity of the alliance's members against aggression from a third party. In order to create a tighter security cooperation in 2002 an organisational reform was implemented when Organisation of Collective Security Contract was established, and still operates to this day. ${ }^{15}$ These organisations are important elements of Moscow's foreign policy where strong Russian dominance applies, so with their help Russia can carry its weight in the post-Soviet area. Of particular relevance is the situation of the South-Caucasian region that has strategic meaning for Russia due to its geographic location and its role in energy transportation. There are many

13 Sputnik News: New Russian Nat'l Information Security Doctrine to Be Finalized in 2016. http://sputniknews.com/russia/20160204/1034195710/russia-information-security-doctrine.html, Time of download: 26.05.2016.

${ }^{14}$ The organisation has 9 stable and one associated member - Georgia after the war in 2008 - while the Ukraine seceded from the CIS in 2014. See: Éva Lipusz: Organization of Collective Security Contract. Art of war, XXIII. year, 1. electronic number, 2013. http://mhtt.eu/hadtudomany/2013/2013_elektronikus/2013_e_lipusz_e va.pdf, Time of download: 24.05.2016.

${ }^{15}$ The organisation was originally created by Russia, Armenia, Kazakhstan, Kyrgyzstan, Tadzhikistan and Uzbekistan that was joined later by Belarus, Georgia and Azerbaijan. 
important transit cables that run through the South-Caucasian region that transport crude oil and natural gas out of the Caspian Sea's stations toward Europe. In the years after the Soviet Union's collapse, the region changed into a "geopolitical battlefield" as a result of the political and economic rivalry among the area's regional powers - Russia, Turkey and Iran as well as Western countries, and primarily the United States. In this contact it can be pointed out that Russia remained the most significant economic and military power in the SouthCaucasian region, although in certain countries Washington's political and economic influence has grown perceptively(Besenyő, 2008) ${ }^{16}$. It's important to mention that in order to counterbalance Russian influence, the Ukraine, Georgia, Azerbaijan and Moldova established the so-called GUAM group in 1997 in order to secure the Caspian-Sea's oil transport route by avoiding Russia (Bíró, 2014) ${ }^{17}$. One of the main goals of these countries was to ease their post-independence reliance on Russia via a political and economic approach to the West. According to the Kremlin's standpoint, the Western efforts to attract contemporary republics of the former Soviet Union were intended to trap Russia in the first place. Therefore, Moscow's geopolitical goals also significantly influence the freedom of the region's countries alongside their economic interests in the question of transit pipelines. Considering this, it is not surprising that the relations between Georgia - gaining its independence in 1991 - and Russia were already strained right from the beginning and were characterised by an atmosphere of mutual distrust. In this, a crucial role is played by the Russian military bases in the country, the issue of the two separatist republics - South-Ossetia and Abkhazia - as well as the divergent economic interests appearing in the issue of the oil pipeline from the CaspianSea. Since the beginning, Russian management took Georgia's attempts to move toward the West adversely; therefore, Moscow - in order to keep his influence in the South-Caucasian region - tried to put pressure on the country (Ellison, 2011) ${ }^{18}$. Russian management complained many times that with the active help of Washington, pro-Western democracies become established in Russia's "strategic back yard"; in this regard they mentioned Georgia and the Ukraine as examples. Moscow warned the Ukraine and Georgia many times that their approach to NATO might have negative political consequences since this forces Russia to give an appropriate response to them (Tracey, 2009) ${ }^{19}$.

\footnotetext{
16 pp. 61-63.

17 p. 46. www.nemzetesbiztonsag.hu/letoltes.php?letolt=552, Time of download: 24.05 .2016

18 p. 346. https://www.gwu.edu/ ieresgwu/assets/docs/demokratizatsiya\%20 archive/GWASHU_DEMO_19_4 /0367216M621448T3/0367216M621448T3.pdf, Time of download: 24.05.2016

19 p. 226.
} 


\section{Russian-Georgian relations in the pre-war years}

A brief review of Russian-Georgian relations prior to the war is relevant here. The roots of the conflict go back to 1991; the Georgian state regaining its independence was marked at this time by intense instability and ethnic tensions, firstly felt in South-Ossetia, and then in Abkhazia when bloody conflict erupted (Benes, 2014) ${ }^{20}$. With Russia's mediation the Sochi Agreement of 1992 put South-Ossetia's situation in order, while in Abkhazia the Moscow Agreement, which ended the long-lasting fights in 1994, made it possible to bring UN-navigators while the CIS troops provided peacekeepers. With the appearance of the Russian peacekeepers and the UN-navigators the conflict went into hibernation, but it did not reach a comprehensive political settlement. ${ }^{21}$ The tension between Georgia and Moscow did not cease either, which can be explained by the different goals of the two countries. Russia strove to regain its political, economic and military influence in the post-Soviet area that had been lost due to the Soviet Union's split. This process accelerated when Vladimir Putin rose to power in 1999; Moscow stepped forward with ambitions of being a world power with a concurrent and significant economic surge in the second half of 2000. Unavoidably, this generated a conflict with Georgia, a country that had started to build a nation, in particular after the political turn in 2003. After ending the conflict in Abkhazia and South-Ossetia, the Georgian government with its leader, Eduard Shevardnadze endeavoured to put their relations with the Russian government in order. Therefore, Georgia joined the CIS on 21 October 1993 and became a member of the OCSC on 9 December 1993. Subsequently, the RussianGeorgian Cooperation Agreement was signed during Boris Yeltsin's presidential visit to Tbilisi in 1994. At the end of the decade this political inclination swung westwards, motivated by the demand to resolve the two dormant conflicts and recover the country's territorial integrity. All these were supported by the growing interest of the United States in the area, and there was a political turn in 2003 called the "Rose Revolution", the construction of the Baku-Tbilisi-Cheyenne oil pipeline in 2005 as well as military support assured by the Americans. Then Georgia exited OCSC in 1999, and, more importantly, made the Russian

\footnotetext{
${ }^{20}$ Besides Adzharia also proclaimed de-facto independence that lasted until 2004 - then the Georgian troops restored the control of central government based on the command of Mikheil Saakashvili in the area. See: p.74. uni-nke.hu/downloads/kutatas/folyoiratok/hadtudomanyi_szemle/szamok/2014/2014_4/2014_4_bp_benes.pdf, Time of download: 24.05.2016

21 Ibid. p. 77.
} 
bases on its territory got closed down. The process accelerated significantly after Mikheil Sakashvili rose to power, and finally came into a conflict in $2008 .^{22}$

Summarising the facts: after fighting at the beginning of the 1990s, the Abkhaz and South-Ossetia territories fell under Russian protection, and their population was militarised (Tracey, 2009) ${ }^{23}$. The attempts of the Georgians to resolve the issue - which also opened the option of autonomy within Georgia - failed one after the other partially because there was no Western pressure on Moscow to resolve the dormant conflict (Besenyö, 2008) ${ }^{24}$. In the years prior to the war in 2008, Russia gave citizenship to the population of the separatist states as well as easing the economic and bureaucratic ties with them (Tracey, 2009) ${ }^{25}$. Providing Russian citizenship was an important tool for Moscow that gave an opportunity for military intervention, respectively questioning and undermining Georgia’s sovereignty.

\section{The direct processes that led to the conflict}

In connection with the direct series of events leading to the outbreak of war, the standpoints of the Russian and Georgian parties are in opposition. Any judgment over who bears direct responsibility for the outbreak of the war exceeds the scope of this monograph, so a short review of the events will suffice, which took a different course after Kosovo's declaration of independence on 17 February 2008 (Tracey, 2009) ${ }^{26}$, after the Russians hinted at an official acceptance of the two separatist republics. The declaration on the NATO-summit in Bucharest in April 2008 only deepened the disagreement further, intimating that Ukraine and Georgia could become members of the Alliance (Sztáray, 2008) ${ }^{27}$. In this period of the conflict, Moscow supplemented political and diplomatic pressure with military means that created the requirements of a military action against Georgia. An important milestone in the process that led to war was an incident on 20 April when the Russian air force shot down a Georgian reconnaissance aircraft without a $\operatorname{pilot}^{28}$ after which conflict erupted and led to a

\footnotetext{
22 Ibid. p.78-79.

23 p. 233.

24 pp. 61-63.

25 p. 233.

26 p. 235.
}

${ }^{27}$ p. 27, http://kki.gov.hu/download/4/7b/b0000/Kulugyi_Szemle_2008_02_Bukarest_a_felem\%C3\%A1s_ d\%C 3\%B6nt.pdf, Time of download: 24.05.2016.

${ }^{28}$ United Nations Observer Mission in Georgia (UNIMOG): Report of UNOMIG on the Incident of 20 April Involving the Downing of a Georgian Unmanned Aerial Vehicle Over the Zone of Conflict. 2008. http://www.securitycouncilreport.org/atf/cf/\%7B65BFCF9B-6D27-4E9C-8CD3CF6E4FF96FF9\%7D/Georgia\% 20UNOMIG\%20Report\%20on\%20Drone.pdf, Time of download: 24.05.2016. 
fast escalation. The Russians harnessed their peacekeeping forces in Abkhazia ${ }^{29}$. The Georgian leaders interpreted this move as an impending annexation of the separatist republic as well as military intervention and, in response, Georgia took the necessary steps and put its army on red alert. It is relevant to note that the Georgian leaders - under the Bush administration's advice - took heed not to provoke Moscow, nor create a reason for any

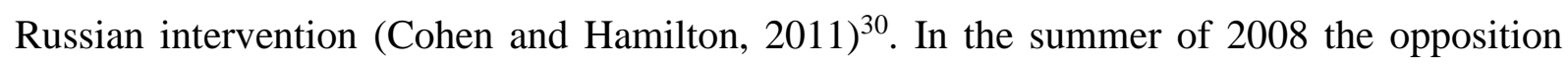
conducted military manoeuvres. Some authors noted that the manoeuvre in July called "Caucasus 2008" 31 can be considered as a rehearsal for war as Russian troops in the NorthCaucasus Military District offered assistance to the peacekeeping forces stationing in

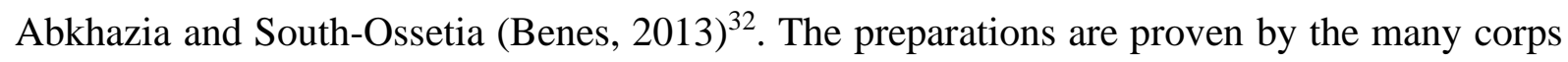
that did not return to their appointed stations after the practice manoeuvres as well as the 58th Army remaining on alert (Pallin and Westerlund, 2009) ${ }^{33}$. On the eve of the war both parties accused the other about the conflict on the Georgian- - South-Ossetia border that claimed fatalities that then led to Georgian military operations on 8 August in order to recapture South-Ossetia.

Overall, it can be stated that the official Russian terminology referred to the Georgian intervention as a peacekeeping operation (Cheteriana, 2009) ${ }^{34}$, which according to Western experts was a deception of international public opinion (Pallin and Westerlund, 2009) ${ }^{35}$. Many analysts have highlighted (Cohen and Hamilton, 2011) ${ }^{36}$ that the Russians were thoroughly prepared for the Georgian intervention. Some more facts may prove this: the significant manpower as well as the rapid implementation of techniques at the beginning of the conflict. All this goes to show that the Russian leaders had expected an incidental armed

\footnotetext{
${ }^{29}$ In May, the Russians confirmed the headcount of peacekeeping forces stationed in Abkhazia. Their number grew after this to 2500 . Then at the end of the month a railway contingent of 400 people was deployed in the separatist republic. See: Ellison, Brian J.: Russian Grand Strategy in the South Ossetia War. Demokratizatsiya: The journal of post-Soviet democratization, 19-4, 2011., p. 352.

${ }^{30}$ p. 18., http://www.strategicstudiesinstitute.army.mil/pdffiles/PUB1069.pdf, Time of download: 20.05.2016

${ }^{31}$ Parallel to this was the multinational NATO manoeuvre called "The Immediate Response 2008" in Georgia that involved a total of 1650 soldiers in the program Partnership for peace. See: Ellison, Brian J.: Russian Grand Strategy in the South Ossetia War. Demokratizatsiya: The journal of post-Soviet democratization, 19-4, 2011,

${ }^{32}$ p. 92., http://uni-nke.hu/downloads/kutatas/folyoiratok/hadtudomanyi_szemle/sza mok/2013/2013_3/2013_ 3_bp_benesk.pdf, Time of download: 20.05.2016

33 p. 405.

${ }^{34}$ Russia referred to Georgian holocaust in South-Ossetia and attacks on the Russian peacekeeping forces stationed in the area while Georgia referred to Russian realignment to the area of South-Ossetia in regard to the outbreak of war. See: V. Cheteriana, 2009, p. 156.

35 p. 404.

${ }^{36}$ p. 1.
} 
conflict for a long time in the Caucasus, and prior to the war they prepared their forces stationed in the area.

\section{The war's events}

The scope of this monograph does not allow for a detailed description of the conflict, so a short review of the events must suffice. Overall, it seems that the main goal of the Georgian operations for the recapture of South-Ossetia (Pukhoy and Glantz, 2010) ${ }^{37}$ was to take the capital city of Chinvali and then secure the strategically important Rok-NyizsnyijZamarag passage (Sándor, 2013) $)^{38}$. In spite of initial successes, the invasion came to a standstill, and when the Russian army counterattacked, Georgian troops began to retreat from South-Ossetia on 8 August in the afternoon. The appointed corps of the 58th Army ${ }^{39}$ intervened in the separatist republic and released Chinvali from siege. In tandem with this operation, two bombers, three supporting aircrafts and the Helicopter Regiment of the 4th Air Forces intervened against the Georgian forces as well as military targets in their hinterland. ${ }^{40}$ On 10 August, on the instruction of the Russian Ministry of Defence, 9,000 soldiers and 350 armoured combat vehicles entered Abkhazia; its government mobilised the troops on 11 August, gave Georgia an ultimatum, demanding the evacuation of the Kodori Valley which was of high strategic value. ${ }^{41}$ Since Georgia declined, on 12 August Russian and Abkhaz troops invaded part of the country, thus opening new fronts. Next to the operations in Abkhazia fighting also broke out at sea and the Russian Black-sea navy destroyed many Georgian naval vessels in the harbour of Poti. The Russian troops broke the resistance of the Georgian forces that were gradually moving back towards the capital. Medvedev, the Russian president, finally announced the termination of Russian operations on 13 August around noon and subsequently, that night Russia and Georgia made a ceasefire arrangement - with French assistance.

\footnotetext{
${ }^{37}$ The Georgian forces in the attack consisted of 12,000 soldiers and $72 \mathrm{~T}-72$ tanks at the beginning, p. 47., http://www.cast.ru/files/The_Tanks_of_August_sm_eng.pdf, Time of download: 24.05.2016

38 This passage ensures a direct connection between Russia and South-Ossetia and a successful lock-down would have made it significantly difficult to launch a Russian counterattack. See: p. 7., old.biztonsagpolitika.hu/documents/13727658 26_Vizi_Sandor_a_gruz_orosz_haboru_2008_bizt onsagpolitik a.hu.pdf, Time of download: 24.05.2016

39 The headcount of the incoming Russian forces amounted to 14,000 soldiers, 100 tanks, 100 self-propelled guns, 40 multiple rocket launchers, 400 infantry fighting vehicles and 200 armoured fighting vehicles. See:

Ibid, p. 8.

${ }^{40}$ Ibid. p.7.

${ }^{41}$ Ibid. p. 8.
} 


\section{The characteristics of the information operations during the Russian- Georgian war in 2008}

During the Russian-Georgian war in 2008 Georgia experienced how it is when a country is attacked via the Internet. Hackers opened the Internet front by blocking Georgian servers and making communication impossible throughout the country. Official websites collapsed one after the other having been overloaded with thousands of queries at the same time. It is likely that the $\operatorname{DDoS}^{42}$ attacks were a part of the pre-war last test of this type. This form of attack belongs to the first type where the opponents went on the offensive before the outbreak of war in cyberspace. Considering that attacks via cyberspace do not require any major financial investment, it is likely that this form of threat may also be expected later on. The attacks accelerated at the time of the Russian intervention in South-Ossetia.

The attacks were implemented in two steps. Firstly, the Georgian governance was denied access to the Internet, thus it could not influence the perception of foreigners visiting Georgian websites.. This is what happened when, after the Georgian National Bank's website was hacked, President Mikheil Saakashvili appeared on the webpage with dictators. They drew a moustache on the head of state and depicted him in poses like a Nazi dictator. In the second step they strove to misinform the population. By blocking communication, media and blogs, the people were misinformed. While discrediting the head of the state, many websites were also created in order to discredit the country and mislead the population. ${ }^{43}$ The perpetrators were cloaked in invisibility and both opponents accused the other of the attacks. ${ }^{44}$ Despite this, the disruption in telecommunication services clearly showed that the overload attacks were closely related to military steps. ${ }^{45}$ American system administrators pointed out that the attacks had been conducted, inter alia, via a machine developed to send spam; the Russian Business Network could have been behind this. ${ }^{46}$ The director of Secure Works ${ }^{47}$,

\footnotetext{
${ }^{42}$ Distributed Denial of Service (DDoS) - overloading attack.

${ }^{43}$ It is important to note that websites ending in .ru were inaccessible throughout the country - according to unconfirmed sources they were banned by the Georgian government.

44 John Markoff - The New York Times - Before the Gunfire, Cyber attacks http://www.nytimes.com/2008/08/13/technology/13cyber.html?ref=europe, Downloaded: 28.05.2016.

45 Atlantic Council - Russian Cyber Strategy and the War Against Georgia http://www.atlanticcouncil.org/blogs/natosource/russian-cyber-policy-and-the-war-against-georgia, Downloaded: 01.06.2016.

${ }^{46}$ Russian Business Network - Georgia Cyber Warfare http://rbnexploit.blogspot.hu/2008/08/rbn-georgiacyberwarfare.html, Downloaded: 01.06.2016.

${ }^{47}$ Company.
} 
Don Jackson stated that "the hackers utilized the same tools and instructions against the Georgian computers as the Russian Business Network." 48

Generally, as regards the effectiveness of the information operations, it may be pointed out that since Georgia did not have a developed information network at this time and did not suffer the same damage as, for example, Estonia where banking services were completely paralysed, amongst other problems. Furthermore, it may be concluded that attacks delivered through cyberspace can only yield effective results if the attacked party has a well-developed information technology network. In case of Georgia, this was not the case and so, despite their importance, physical operations played a larger role during the war than activities performed through the cyberspace.

\section{Conclusions}

Due to the five days long conflict a significant political, economic as well as military realignment occurred in the region showing that Russia is prepared to involve its armed forces to achieve its goals. This is expressed in Russian president Dmitry Medvedev's speech after the war, according to which Russia is ready to protect its "privileged interests" in the "middleabroad" with any possible tools (Özkan, 2012) ${ }^{49}$. According to most experts, the war is commended as a Russian success since Russia reached its main strategic goal: they prevented Georgia joining NATO and Russian influence grew in the region accordingly. This was a message to the West as well as other states in the area. Russia demonstrated that it is strong enough to even undertake an open confrontation to protect its interests in the direct geographical and strategic environment. Moscow succeeded in intimidating some countries in the region - first and foremost, Ukraine - redirecting them to the Russian sphere of interest. Russia's ambition fits with the process of moulding the OCSC into a real political and military alliance after the war by strengthening the organisation's peacekeeping capability and military cooperation among the member states. ${ }^{50}$ Moscow's goal thereby was to establish a counterbalance to NATO, reducing its political and military flex in the region. Moreover, Russia enforces its military political interests as the organisation exerts control over the member states. The examples of the Georgian and Ukrainian conflict show that Russia uses the OCSC for its own geopolitical ends, thus providing legitimacy for Russia's regional

\footnotetext{
48 Russian Business Network - Georgia Cyber Warfare http://rbnexploit.blogspot.hu/2008/08/rbn-georgiacyberwarfare.html, Downloaded: 01.06.2016.

49 p. 36.

${ }^{50}$ Ibid, p. 48.
} 
military interventions. ${ }^{51}$ After the war, the United States, Turkey and the European Union speeded up their efforts to build the Nabucco oil pipeline that aimed at reducing their dependence on Russia. As the Russians justified the pipeline from a geopolitical point of view ; With this background, the goal of reducing Russia's regional bearing was the economic necessity. ${ }^{52}$ In response, the Russians elevated their efforts in regard to building the South Stream that would have ensured Moscow's influence in the southern Caucasian energy sector.

In the course of the military operation, Russia achieved its main strategic goal and the area of South-Ossetia and Abkhazia fell under Russian control. Thanks to the Russian stations established in the separatist republic, Russia's strategic position strengthened significantly in the southern Caucasus. This was also because geographical obstacles - Rokipassage -ceased to be to a natural barrier for the Russian army heading to the south. The other important goal of the operation was to hinder the arrival of back-up Georgian troops, so the Russian air force attacked the Georgian reserves, in addition to important roads and railways, harbours and air bases. Some authors who studied the activities of the Russian air forces came to the conclusion that the destruction of the Georgian military infrastructure and technical stock could have neutralised their offensive capacities (Pallin and Westerlund, 2009) ${ }^{53}$.

To summarise, it can be mentioned that prior to the war the Russians succeeded in internationally isolating Georgia through a number of political and military steps that greatly supported the operation's success. On an operational level, the fast transfer of manpower and tools to the operational area, that encompassed establishing coordination, on tactical level the collective effect of tackling initiation, numerical superiority and rapid advance ensured victory over the - in many cases technically better equipped and educated - Georgian troops. According to some experts, the Russian-Georgian armed conflict in 2008 may be considered as "the last war of the 20th Century" where a military operation led by mostly Soviet principles was applied, first of all in the sense that it was suitable for a large conventional war and executed through outdated methods as well as a management-led system (Bukkvoll, $2009)^{54}$. Considering this, it is not surprising that despite the victory in Georgia, the operation highlighted numerous deficiencies that induced Russia to start an intensive operation modernisation program. In terms of the war, most experts observed that the major

\footnotetext{
${ }^{51}$ See the mutual OCSC declaration that was published after the Georgian war. Ibid p. 49.

52 Ibid, p. 57.

${ }^{53}$ p. 401.

54 p. 61.
} 
deficiencies, besides obsolete technology, involved ineffective cooperation of the overland and air military force management first and foremost. Furthermore, there was a lack of precise weaponry, but electronic inefficiencies were also discovered: the Russian air force could not hold up the Georgian air protection since they had no artillery surveillance radars (Pallin and Westerlund, 2009) ${ }^{55}$. Some authors drew attention ${ }^{56}$ to the Russians - studying previous armed conflicts fought by the West- utilising new principles and methods during the war, so they carried out an extended information operation parallel to the military operations.

In connection with this, it can be generally stated that the emphasis on the information operation largely contributed to the success of the Russian strategy in terms of undermining the Georgian government. In this regard, a number of Russian experts criticised the Russian military management because they had not established Information Warfare Units within the armed forces. Many thought that the Russian army did not have a sufficient number of educated professionals at its disposal who could have executed the operations professionally and efficiently. In the framework of the military modernisation program, such concepts developed further and had consequences during the Crimea crisis in 2014. Previously, thanks to post-war developments in 2008, Russian cyber capacities improved considerably and posed a serious challenge to NATO. Recognising this, the member states of NATO and the European Union intensified their cooperation and in the future they must step up together against Russian disinformation spread via an information operation and any offensive activities in cyberspace. ${ }^{57}$

\footnotetext{
55 p. 401.

56 Ibid. p. 404.

57 See: North Atlantic Treaty Organization: NATO and the European Union enhance cyber defense cooperation NATO and the European Union enhance cyber defense cooperation. 2016.
} 


\section{References}

Benes, K., 2013. The impact of the Russian-Georgian war in 2008 on the European security. Hadtudományi Szle.

Besenyő, J., 2008. New kind of War? Internet warfare in Georgia. Sereg Szle., VI.

Bíró, Z.S., 2014. Security politics of Russia and the post-Soviet area. Nemz. És Biztn.

Bukkvoll, T., 2009. Russia Military performance in Georgia. Mil. Rev.

Cheteriana, V., 2009. The August 2008 war in Georgia: from ethnic conflict to border wars. Cent. Asian Surv.

Chotikuk, D., 1986. The soviet theory of reflexive control in historical and psychocultural perspective: A preliminary study. Naval Postgraduate School. California.

Cohen, A., Hamilton, E., 2011. The Russian Military and the Georgia War: Lessons and Implications. Strategic Studies Institute. Carlisle: PA.

Ellison, B.J., 2011. Russian Grand Strategy in the South Ossetia War. Demokr. J. Post-Sov. Democr.

Geers, K., 2008. Cyberspace and the Changing Nature of Warfare. Hakin9 E-Book. SC Mag. Black Hat.

Hollis, D., 2011. Cyberwar case study, Georgia 2008. Small Wars J.

Keating, K.C., 1981. Maskirovka: The Soviet System of Camouflage. U.S. Army Russian Institute.

Özkan, G., 2012. Spoils of war: impact of Georgia-Russia War on Russian Foreign and Security. Policies in the „Near Abroad”. J. Gazi Acad. View.

Pallin, C.V., Westerlund, F., 2009. Russia war in Georgia Lessons and Consequences. Small Wars Insur.

Pukhoy, R., Glantz, D., 2010. The Tanks of August. Centre for Analysis of Strategies and Technologies.

Ruus, K., 2008. Cyber War I: Estonia Attacked from Russia. Eur. Aff.

Sándor, V., 2013. The Georgian - Russian war 2008. Biztonsagpolitika.hu.

Sztáray, P., 2008. Bucharest - the summit of asymmetric decisions. Külügyi Szle.

Timothy, T.L., 2004. Russia's Reflexive Control Theory and the Military. J. Slav. Mil. Stud.

Tracey, G., 2009. David and Goliath: Georgia and Russia’s Coercive Diplomacy. Def. Stud. J. 